\title{
Spatial patterns and scale-dependent relationships between macrozooplankton and fish in the Bay of Biscay: an acoustic study
}

\author{
Ainhoa Lezama-Ochoa ${ }^{1, *}$, Michael Ballón ${ }^{2,3}$, Mathieu Woillez $^{4}$, Daniel Grados ${ }^{2,3}$, \\ Xabier Irigoien ${ }^{1,5}$, Arnaud Bertrand ${ }^{2,3}$ \\ ${ }^{1}$ AZTI-Tecnalia, Marine Research Unit, Herrera Kaia Portualdea z/g, 20110 Pasaia, Basque Country, Spain \\ ${ }^{2}$ Instituto del Mar del Perú, Esquina Gamarra y Gral. Valle s/n, Apartado 22, Callao, Lima, Peru \\ ${ }^{3}$ Institut de Recherche pour le Développement (IRD), UMR212 EME IFREMER/IRD/UM2, Avenue Jean Monnet, BP 171, \\ 34203 Sète Cedex, France \\ ${ }^{4}$ University of Washington, School of Aquatic and Fishery Sciences, Box 355020, Seattle, Washington 98195, USA
}

${ }^{5}$ Present address: Red Sea Research Centre, KAUST University, Thuwal, Saudi Arabia

\begin{abstract}
Macrozooplankton plays a key role in pelagic ecosystems as a link between lower trophic levels and fish. However, although its ecological role is usually considered in polar ecosystems, it is rarely considered in temperate ones. To obtain comprehensive information on the macrozooplankton distribution in the Bay of Biscay we adapted a bi-frequency acoustic method developed for the Humboldt Current system. This method can be used to extract continuous and simultaneous high-resolution information on the spatiotemporal patterns of biomass distributions of macrozooplankton and pelagic fish throughout the diel cycle. The 2 distributions were mapped using geostatistical techniques. We applied kriging with external drifts, which accounts for both diel and across-shore changes in macrozooplankton biomass. We then used a cross-variogram to determine the scale-dependent relationships between macrozooplankton and fish. The results show how macrozooplankton and fish are distributed according to the different ecological domains (coast, shelf, shelf-break and offshore) along the Spanish and French coasts. Specific macrozooplankton hotspots were observed, but macrozooplankton was generally more abundant offshore than inshore, whereas fish showed the opposite trend. This pattern was confirmed by the aggregation sizes, which increased towards oceanic waters for macrozooplankton and decreased for fish. Finally, the correlation between fish and macrozooplankton was positive on a small scale ( $<30$ nautical miles) and negative on a large scale ( $>30$ nautical miles).
\end{abstract}

KEY WORDS: Macrozooplankton - Pelagic fish · Acoustics $\cdot$ Spatial pattern $\cdot$ Scale-dependent interaction · Bay of Biscay

Resale or republication not permitted without written consent of the publisher

\section{INTRODUCTION}

Zooplankton plays a crucial role in structuring higher and lower trophic levels, and influences the population dynamics of exploited species (Carlotti \& Poggiale 2010). Although the ecological compartment that zooplankton represents is essential for a mechanistic understanding of the ecosystem dynamics, in general the data on zooplankton are scarce and of low quality (Mitra \& Davis 2010), mainly because zooplankton abundance and distribution are generally assessed based on net sampling (Omori \& Hamner 1982, Wiebe et al. 1985, Ohman \& Smith 1995). Although net sampling provides valu- 
able information on zooplankton species composition, abundance and time series (Ohman \& Smith 1995, Verheye \& Richardson 1998), net data are discrete in space and time, and are usually biased for macrozooplankton ( $>20 \mathrm{~mm}$ in size) (Mackas \& Beaugrand 2010). Furthermore, macrozooplankton can react to both visual and mechanical disturbances and avoid net sampling, particularly vertical tows (Fleminger \& Clutter 1965, Brinton 1967, Debby et al. 2004, Lawson et al. 2008). Therefore, despite the importance of macrozooplankton in biogeochemical cycles and the energy flow of marine pelagic ecosystems (Robinson et al. 2010), there are not enough data, particularly high-resolution data, to fully understand its ecological role (Siegel 2000). High-resolution zooplankton data are necessary for matching physical and biological processes and determining, for instance, mesoscale oceanographic structures (Gil et al. 2002).

As acoustics are not invasive, they can be used to sample organisms that otherwise would be missed or underestimated by net sampling; for example, acoustics are routinely used to estimate krill biomass in the Antarctic (e.g. Watkins \& Brierley 2002, Lawson et al. 2008). This method allows high-resolution qualitative and quantitative data of various communities of an ecosystem to be collected simultaneously, from zooplankton to large predators (Bertrand et al. 2003, Koslow 2009).

In the Bay of Biscay, most of the study effort has been focused on fish, whereas little attention has been paid to zooplankton, particularly micro- and macrozooplankton (Beaudouin 1971, 1975, 1979, Quevedo \& Anadón 2000). Actually, although large macrozooplankton aggregations are regularly observed with acoustics (Lezama-Ochoa et al. 2010), a broad picture of the macrozooplankton distribution has not yet been determined.

The objective of this study was to use a bifrequency acoustic method developed in the Humboldt Current system by Ballón et al. (2011) to gain a better understanding of the macrozooplankton community distribution and its role in the Bay of Biscay ecosystem. This method can be used to obtain continuous and simultaneous high-resolution information on macrozooplankton and pelagic fish biomass distributions.

We first described the horizontal distribution patterns of macrozooplankton and fish biomass according to different spatial scales and the diel period. Then, we used the simultaneous data on macrozooplankton and fish to determine the scale-dependent relationships between them.

\section{MATERIALS AND METHODS}

\section{Acoustic data acquisition}

Acoustic data were recorded with Simrad EY60 split-beam scientific echosounders at 38 and $120 \mathrm{kHz}$ (Kongsberg Simrad AS) during a scientific routine survey performed in spring (April-May) 2009 within the BIOMAN program (AZTI project) in the Bay of Biscay. BIOMAN surveys estimate the anchovy Engraulis encrasicolus spawning biomass using the daily egg production method. They provide a large number of acoustic measurements, mesozooplankton (0.2-20 $\mathrm{mm}$ in size) samples, physicochemical measurements and pelagic trawl hauls (Motos et al. 1996).

The sampling area covered the Bay of Biscay (the Cantabrian Sea and off the French coast), with the westbound survey limit at $5^{\circ} \mathrm{W}$ and the northbound survey limit at $47^{\circ} \mathrm{N}$ (Fig. 1). Sampling was performed during both the day and night. The survey design was a combination of systematic and adaptive schemes. The systematic scheme was based on cross-shelf transect lines from the coast (bottom depth $\sim 20 \mathrm{~m}$ ) to beyond the shelf-break. Transects were parallel, regularly spaced and perpendicular to the coast with an inter-transect distance of 15 nautical miles (n mile). Standard transects extended 6 to $10 \mathrm{n}$ mile off the shelf-break if no anchovy eggs were found further from the shelf-break. Otherwise, transects were prolonged as long as eggs were detected and then stopped when no eggs had been found in $6 \mathrm{n}$ mile. This adaptive scheme was adopted to ensure that the anchovy spawning area was covered completely.

The echosounder was calibrated in accordance with Foote et al. (1987). The water column was sampled down to depths of 300 and $500 \mathrm{~m}$ for the 120 and $38 \mathrm{kHz}$ channels, respectively. As there was electric noise in the echograms (surveys were performed onboard commercial vessels), only the first $150 \mathrm{~m}$ were considered. The acoustic data were selected, classified and analyzed with Echoview (SonarData) and MATLAB (MathWorks) software.

\section{Bi-frequency classification method}

Acoustic echoes were discriminated with a bifrequency acoustic method developed by Ballón et al. (2011). This method uses the 38 and $120 \mathrm{kHz}$ frequencies to extract continuous and simultaneous high-resolution information on the spatiotemporal patterns of pelagic fish and 'fluid-like' organisms 

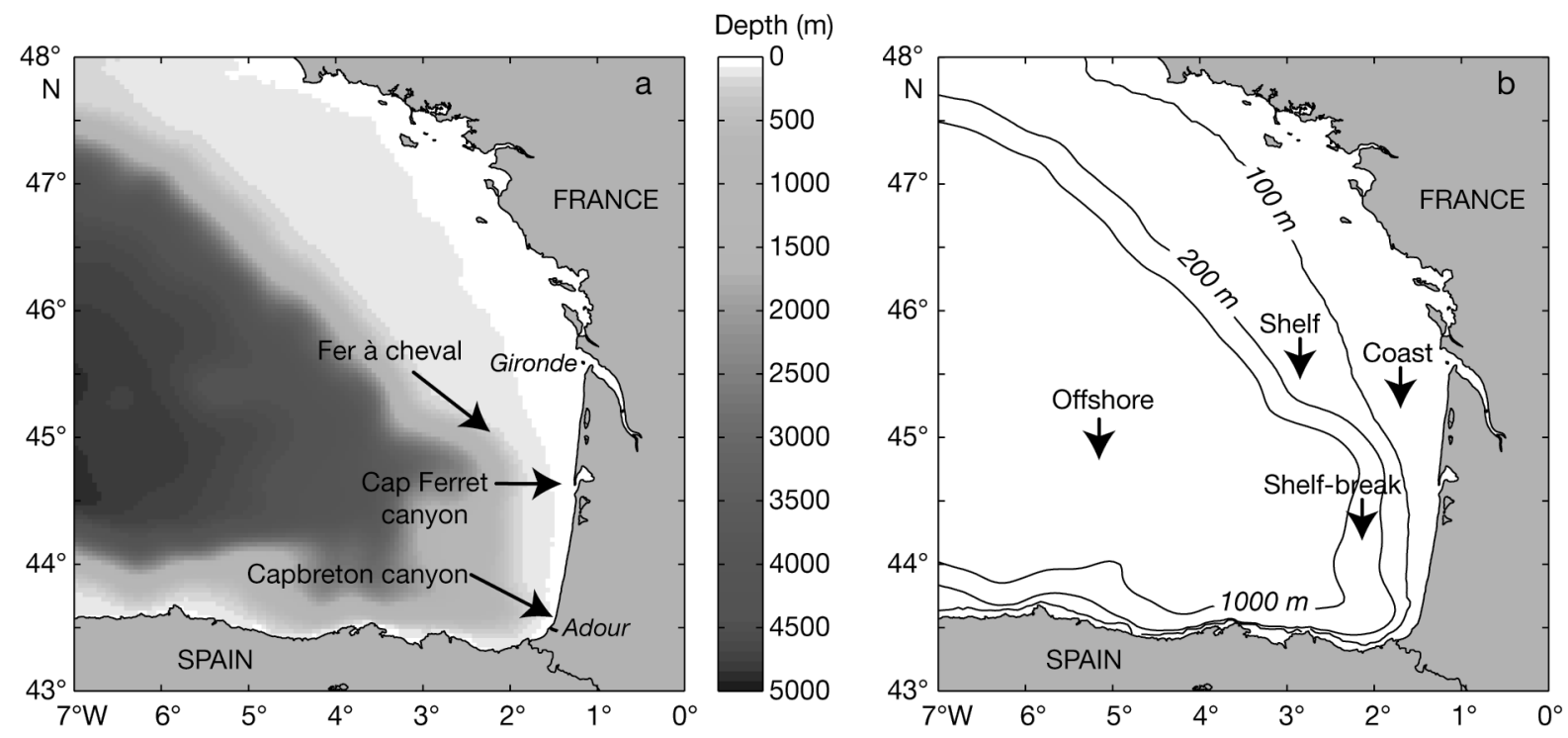

Fig. 1. (a) Bathymetry map (m) of the study area. River mouths and specific topographic features are indicated, as well as shelf areas (coasts). From light grey to dark grey, polygons represent the coast, shelf, shelf-break and offshore areas. (b) Location of the ecological zones identified in the BIOMAN campaigns

(Stanton et al. 1996), mainly euphausiids and large copepods (Fig. 2).

Except for a few modifications, the method was applied directly in the Bay of Biscay.

\section{Pre-processing: removing noise and resampling}

First, the ping number and position between echograms were synchronized using the matching ping number algorithm from Echoview. The noise from the surface (5 $\mathrm{m}$ depth from the transducer) and any bottom echoes were excluded. The echograms were cleaned by defining and eliminating regions containing parasite noise (unwanted signals present in the medium but independent of the echosounder transmission; Urick 1986) or a 'school tail' (diffuse ragged tail below the more solid mark of the school). The noise associated with the acoustic absorption was eliminated (Korneliussen 2000, Fernandes et al. 2006) using the following noise function:

$$
20 \log (R)+2 \alpha R+O
$$

where $R$ is the range (m), $\alpha$ is the frequency absorption coefficient $\left(\mathrm{dB} \mathrm{m}^{-1}\right)$, and $O$ is the offset value $(\mathrm{dB})$, i.e. the assumed initial noise in the first meter.

Acoustic scattering is stochastic, and thus it is necessary to average acoustic measurements to reduce natural variations in the data (Korneliussen et al. 2008). Following the recommendations of Korneliussen et al. (2008), the bi-frequency echograms were resampled in common elementary cells with a length of 1 ping and a height of $0.80 \mathrm{~m}$ (from 4 raw cells $0.2 \mathrm{~m}$ in height). Ballón et al. (2011) used the oxycline as a natural barrier to define the vertical extension of the epipelagic community. In the Bay of Biscay, there is no physical parameter that limits the epipelagic habitat as oxygen does in the Humboldt Current system; thus, we considered the entire observed water column (150 $\mathrm{m}$ or the bottom depth).

\section{Enhancing the contrast between fish and zooplankton backscatters}

The difference between the mean volume backscattering strength of 2 frequencies ( $\triangle \mathrm{MVBS}$ ) is commonly used to determine the characteristics of biological backscatterings (see Murase et al. 2009). Unfortunately, the discriminatory power of scatters is limited when only $\triangle \mathrm{MVBS}_{120-38}$ is applied. For instance, pneumatophores may have an increasing or decreasing trend between the frequencies of 38 and $120 \mathrm{kHz}$ depending on their size, and thus can have a positive or negative $\triangle$ MVBS. The same observation can be made if the 38 to $120 \mathrm{kHz}$ range for a scatter falls within the Rayleigh/geometric transition zone (Stanton et al. 1998), where backscatter efficiency oscillates.

However, a recent methodology (A. LebourgesDhaussy \& P. G. Fernandes unpubl. data), based on the sum of the mean volume backscattering strength (+MVBS) of 2 or more frequencies, enhances the contrast between pelagic swimbladder-bearing fish and other organisms, making them easier to discriminate. 


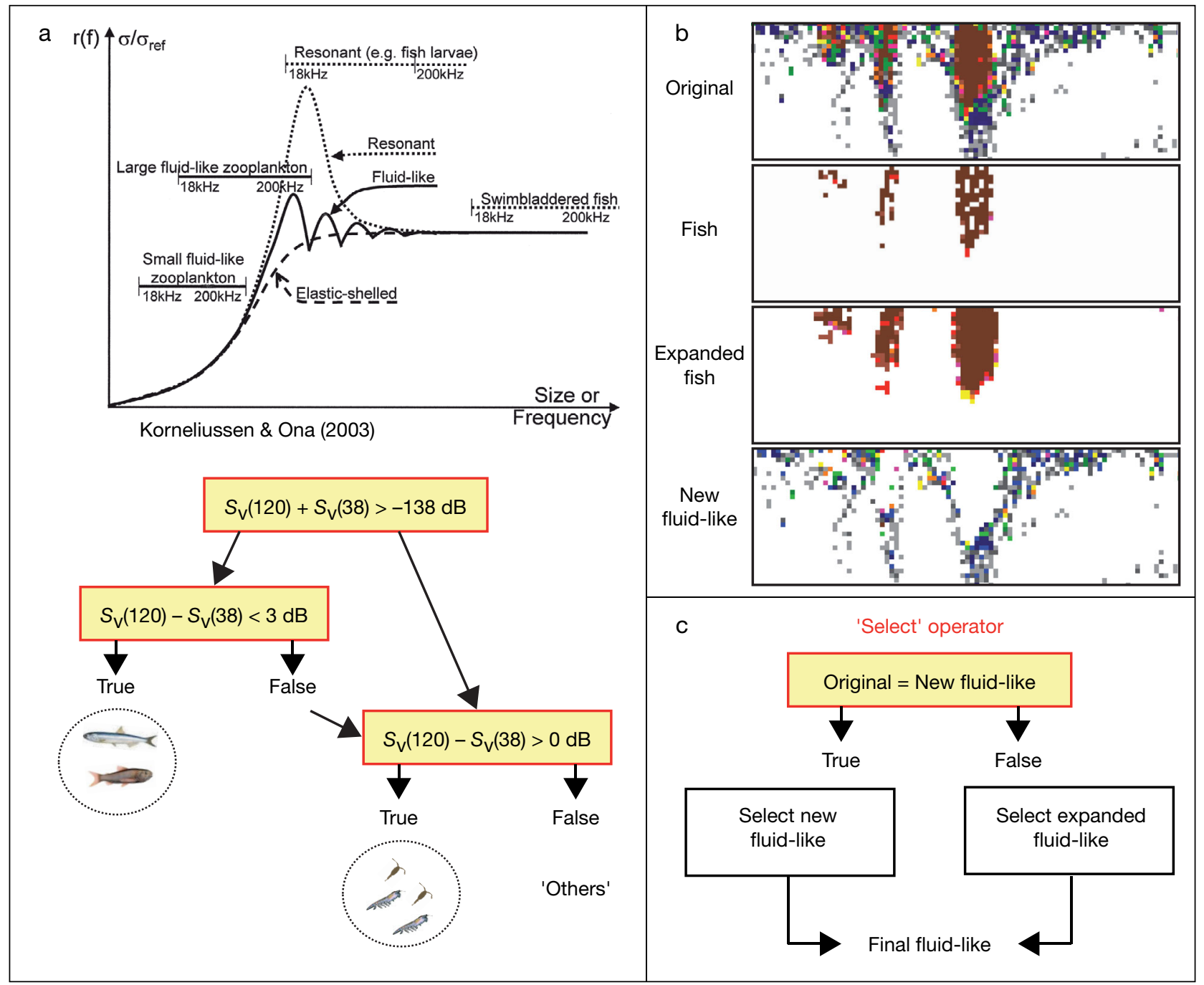

Fig. 2. Main steps of the bi-frequency classification method developed by Ballón (2010) and Ballón et al. (2011). (a) First, discriminate scatters into 'fish', 'fluid-like' and 'others' based on their scattering models. $S_{\mathrm{V}}(x)$ : volume scattering strength, where $x$ is the broadcast frequency $(\mathrm{kHz})$. Reproduced from Korneliussen \& Ona (2003) with permission. (b) Second, refine the discrimination of these groups by using expanded echograms as a Boolean mask. (c) Finally, recompose the final echograms of each scatter following some conditional statements

The method by Ballón et al. (2011) combines both $\triangle$ MVBS and + MVBS to discriminate and quantify the abundance of crustacean macrozooplankton. Therefore, based on observations (expert scrutinizing of the echograms) and exploratory analysis (distribution of volume scattering strength $\left[S_{\mathrm{v}}\right]$ frequencies), a threshold value of $-138 \mathrm{~dB}$ for the sum echogram $\left(+\mathrm{MVBS}_{120+38}\right)$ was chosen and used as a Boolean mask (true for values above the threshold) to extract fish data (above $-138 \mathrm{~dB}$ ) from other scatters (below $-138 \mathrm{~dB}$ ) and create 'fish' and 'no fish' (still not free from weak fish scatters) echograms at each frequency (Fig. 2a). From this point onwards, all processes were applied to both frequencies equally.

\section{Discriminating scatters}

With the exception of mackerel Scomber scombrus, most of the pelagic fish present in the Bay of Biscay, in particular anchovy, sardine Sardinops sagax and horse mackerel Trachurus trachurus, have swimbladders. Therefore, any reference to 'fish' in this study pertains to swimbladder-bearing fish. Swimbladder-bearing fish have slightly higher backscatter at 38 than $120 \mathrm{kHz}$ (Kloser et al. 2002), but there are a few cases of positive $\Delta \mathrm{MVBS}_{120-38}$ (up to $\sim+3 \mathrm{~dB}$ ) in the fish data. We thus refined the fish data from the fish echograms by applying a second Boolean mask in order to keep only the targets for which 
$\triangle$ MVBS $_{120-38}<+3 \mathrm{~dB}$ (Fig. 2a). Although this constraint $(\sim+3 \mathrm{~dB})$ may allow us to include mackerel in this group (Fernandes et al. 2006), we assume that in general any reference to fish in this study pertains to swimbladder-bearing fish.

Zooplanktonic organisms with weakly scattering material and acoustic properties similar to the medium are usually called 'fluid-like' zooplankton (Stanton et al. 1996). The fluid-like group includes euphausiids, copepods, salps, siphonophores (without gas inclusion) and other large crustacean zooplankton (e.g. squilla larvae, munidae and other decapod larvae). This group was extracted from the 'no fish' echograms by applying a Boolean mask to select the targets with a positive $\triangle \mathrm{MVBS}_{120-38}$ (Fig. 2a). Targets with a negative $\triangle \mathrm{MVBS}_{120-38}$ were classified as 'others' ('blue noise' in Ballón et al. 2011). This last group included all targets other than fluid-like zooplankton and swimbladder-bearing fish (mainly fish larvae and gelatinous and gas-bearing siphonophores).

\section{Refining the discrimination}

A preliminary examination of the fluid-like echograms revealed that some targets located inside or at the edge of fish schools were inaccurately selected as fluid-like organisms. In order to extract the remaining fish backscatters from the fluid-like echograms and include them in the final fish echograms, we employed the following 4-step procedure (Ballón et al. 2011) (Fig. 2b):

(1) A copy of the fish echograms was expanded by dilating the value of a cell (containing fish) to its immediate 8 'neighbour' cells $(3 \times 3$ convolution matrix from Echoview);

(2) The expanded fish echograms were used to create a Boolean mask, with false values where fish were present;

(3) This mask was applied to the non-expanded echograms to create new no-fish echograms;

(4) The Boolean mask was applied again to select the targets with positive $\Delta$ MVBS $_{120-38}$ to create new fluid-like echograms.

Although the new fluid-like echograms were almost free from fish echoes, some of the fluid-like targets were also eliminated. Therefore, an additional step was necessary to recompose the fluid-like scatter and obtain our final fluid-like echogram:

(5) Gaps in the final fluid-like echogram were filled by combining the new fluid-like echogram and its expanded version according to a logical bitmap ('select' operator from Echoview). This bitmap has true values for the cells where the original fluid-like echogram has a correspondence value in the new fluid-like echogram and false values otherwise. If there was a true value in the bitmap, then the corresponding data value from the new fluid-like echogram was used, otherwise the corresponding data from its expanded version were used (Fig. 2c).

Similarly, the same procedure was used to include the fish echoes extracted from the fluid-like echograms in the final fish echograms.

Thresholds were then applied on the final echograms of fluid-like organisms ( $38 \mathrm{kHz}$ and $120 \mathrm{kHz}$ ), fish $(38 \mathrm{kHz})$ and others $(38 \mathrm{kHz})$ to eliminate the potential remaining high noise echoes. The upper threshold values were $-21 \mathrm{~dB}$ for fish, $-56 \mathrm{~dB}$ for others, and $-53 \mathrm{~dB}$ for fluid-like organisms $(120 \mathrm{kHz})$, whereas the lower threshold values were $-100 \mathrm{~dB}$ for fish and others (Fig. 3 shows an example of the bi-frequency algorithm).

Finally, as acoustic ping-rates varied from the coast to offshore, the final echograms were averaged over $1 \mathrm{n}$ mile elementary sampling distance units in order to obtain regularly spaced sample data.

\section{Variables of interest}

\section{Acoustic biomass}

The fluid-like group mainly includes euphausiids, copepods, salps and siphonophores (without gas inclusion). In the Bay of Biscay, salps are not common on the shelf but can appear on the slope and offshore (Huskin et al. 2003). Likewise, siphonophores without gas inclusion have a very low biomass (Maycas et al. 1999). Therefore, our fluid-like field was probably mainly composed of euphausiids, but also large copepods, because small fluid-like zooplankton (e.g. small copepods) cannot be properly detected and quantified at the $38 \mathrm{kHz}$ frequency (Mitson et al. 1996).

The lack of in situ net data validation did not allow us to set the method according to a specific group (e.g. euphausiids) and model the data based on its acoustic properties; therefore, this study focused on the whole macrozooplankton community, using an acoustic biomass index $\left(S_{\mathrm{v}}\right.$ in $\mathrm{dB}$ re. $1 \mathrm{~m}^{-1}$ and $S_{\mathrm{v}}$ in $\mathrm{m}^{-1}$ ).

The fish group corresponded to all the small pelagic fish, in particular anchovy, sardine and horse mackerel. Fish acoustic backscattering energy $\left(S_{\mathrm{v}}\right)$ was converted into an acoustic nautical area 
Day

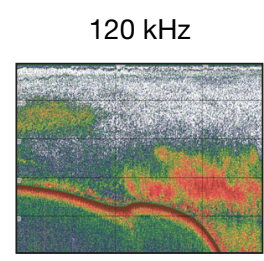

1

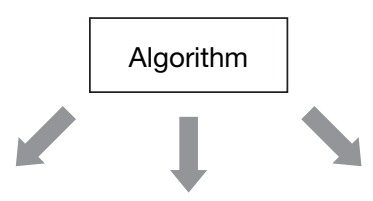

Fish

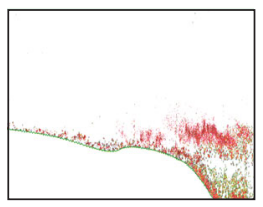

Fluid-like
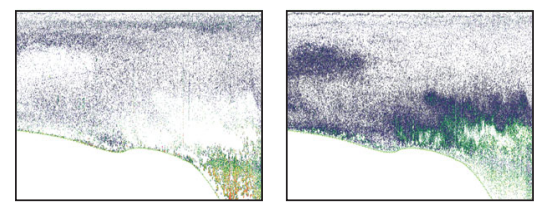

Fig. 3. Example of an application of the
Night
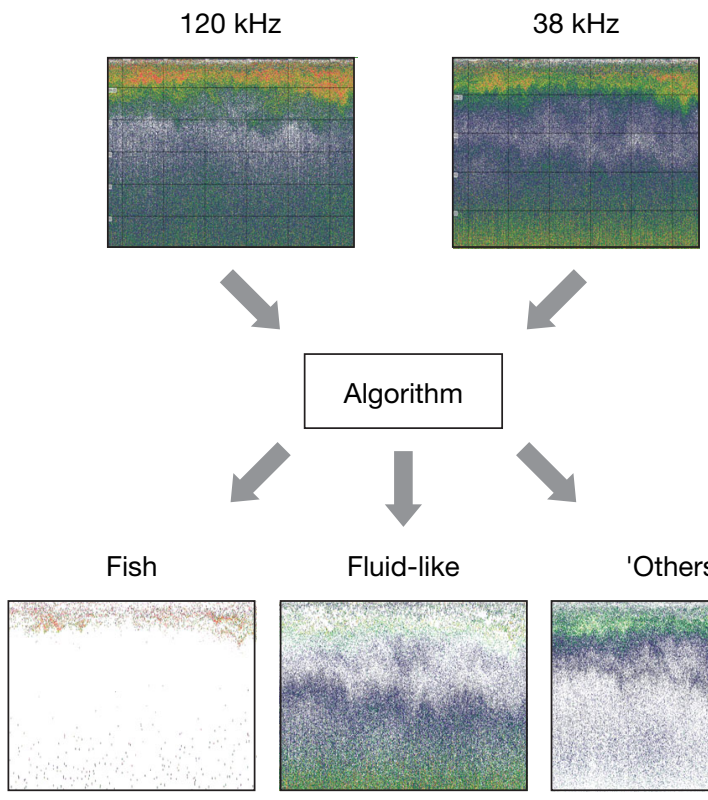

Fluid-like

'Others'
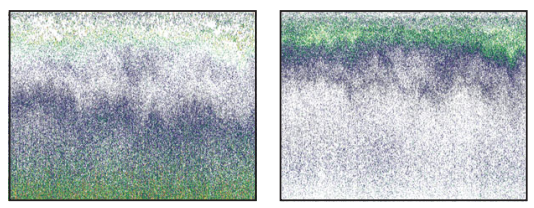
'fluid-like' (macrozooplankton) and 'others'

scattering coefficient $\left(\mathrm{NASC}_{i} \mathrm{~m}^{2} \mathrm{nmile}{ }^{-2}\right.$ ), a biomass index determined according to MacLennan et al. (2002) as:

$$
\mathrm{NASC}=4 \pi(1852)^{2} S_{\mathrm{v}} T
$$

where $S_{\mathrm{v}}=10^{\left(S_{\mathrm{v}} / 10\right)}$ and $T$ is the integrated vertical distance of the elementary cells of $0.80 \mathrm{~m}$.

\section{'Acoustic size' macrozooplankton}

According to Mitson et al. (1996) and Murase et al. (2009), biological backscattering size can be characterized using $\triangle \mathrm{MVBS}$. Therefore, the $\triangle \mathrm{MVBS}_{120-38}$ values from a discriminated group (e.g. the fluid-like group) can be directly related to size classes, assuming that large differences relate to small sizes, and small differences to large sizes.

\section{Defining diel periods}

Diel vertical migration is a common behaviour for zooplankton and nekton. Its effects can be perceived at almost all spatial scales (see Strommel diagram in Haury et al. 1978). The diel vertical migration of macrozooplankton affects the estimations of biomass, density and size, as some species may migrate beyond the range of the acoustic sample $(150 \mathrm{~m}$ for our study). Thus, day and night data were processed independently, and data from the twilight periods \pm 15 min were eliminated in order to focus on consistent light periods.

\section{Exploratory analysis}

For each diel period (day/night), the distribution patterns of macrozooplankton and fish were represented using box plots according to area (Spanish or French), ecological domain (coast: 18 to $100 \mathrm{~m}$ depth; shelf: $100 \mathrm{~m}$ depth to shelf-break [ 200 m depth]; slope: shelf-break ( 200 m depth) to $1000 \mathrm{~m}$ depth; and offshore: $>1000 \mathrm{~m}$ depth) and distance to the shelf-break. Likewise, the patterns of the acoustic size of macrozooplankton were represented using box plots according to ecological domain. Differences between distribution patterns were tested using nested ANOVA with a further post hoc Tukey's test.

The first test shows whether there is a diel effect in each area, and the second test determines whether macrozooplankton and fish biomass significantly differ between domains. However, these statistical tests assumed that the data were distributed normally, which was not the case. Therefore, macrozooplankton and fish biomass were normalized by applying a square-root transformation for macrozooplankton and a logarithmic transformation for fish. The normality of the transformed data was checked using the graphical method of the normal Q-Q plot. 


\section{Geostatistical analysis}

Geostatistics are recognized to be particularly suitable for describing spatial distributions of marine populations. In particular, they provide mono- and multivariate tools for capturing and modelling the spatial structure of a population or highlighting structural relations between 2 populations. Distribution maps can then be produced by interpolation using proper kriging techniques (Simard et al. 1992, Petitgas 1993, Rivoirard et al. 2000).

\section{Structural analysis}

Classic and robust variograms (log back-transformed, Guiblin et al. 1995, Rivoirard et al. 2000) were used to describe the spatial dependence of macrozooplankton and fish, respectively. However, several factors had to be considered: (1) the presence of 2 continental shelves (Spanish and French) with distinct orientations and widths, which meant that the data had to be processed separately because the structure could differ from one area to another; (2) the possible difference between day and night structures due to the diel vertical migration and the aggregation/disaggregation phenomenon; and (3) the shelfbreak as a physical barrier that could induce different spatial structures on both sides of the break.

Therefore, following the scheme introduced in the exploratory analysis, the structural effects of the domain (Spanish and French shelves, offshore and inshore areas, and the entire Bay of Biscay) and the anisotropy or external drifts (Chilès \& Delfiner 1999, Rivoirard et al. 2000) were analyzed for macrozooplankton and fish distributions. In these analyses, 2 external drifts were considered: the diel effect (Rivoirard \& Wieland 2001, Wieland \& Rivoirard 2001) and the vertical acoustic sampling range (150 $\mathrm{m}$ or the bottom depth if shallower). Indeed, the organisms were more or less likely to be detected by the echosounder according to the time of day due to vertical migration and according to the volume sampled in the water column. Finally, a cross-variogram was used to study the spatial interaction between fish and macrozooplankton (Journel \& Huijbregts 1978, Cressie 1993, Goovaerts 1997).

\section{Kriging}

Ordinary kriging was used to map the fish biomass distribution based on a variogram model inferred using a log back-transformed formula (e.g. Rivoirard et al. 2000). Indeed, no significant relationships with any external drift, which would have improved the modelling, were found for the fish biomass.

In contrast, macrozooplankton data were modelled by using ordinary kriging with a day/night indicator and the vertical range as external drifts. The variogram used in kriging with external drift should represent the structured variability of the residuals of the variable, excluding the drift. Thus, raw data were changed for the residuals obtained from a multivariate linear model ( $s_{\mathrm{v}}=\beta_{1}$ vertical range $+\beta_{2}$ day/night indicator $+\beta_{3}+\varepsilon_{\text {; }}$ where $\beta_{\mathrm{i}}=$ regression coefficients, and $\varepsilon=$ error term) when the experimental variogram was calculated (Rivoirard \& Wieland 2001, Wieland \& Rivoirard 2001). This allowed us to produce kriging maps for day and night, when the macrozooplankton is expected to have a stable vertical distribution (i.e. vertical migration has finished). The 2 kriged maps use data from both the day and night, but with a correction applied to the night data for the day map and vice versa.

\section{RESULTS}

\section{Exploratory analysis}

\section{Diel variability in coverage and biomass}

The sampling coverage was different in the day and night (Fig. 4). Night data covered a smaller area than day data because of the longer day periods in summer. Macrozooplankton biomass exhibited significant differences according to diel period (Table 1), with higher macrozooplankton biomass at night (Fig. 5a), whereas fish did not show any significant differences (Table 1, Fig. 5b).

\section{Area effect}

Macrozooplankton biomass did not vary significantly according to the area (Spain or France) in either the night or day (Table 1). In each area, the diel period had a highly significant effect on macrozooplankton biomass (Table 1) with a higher biomass at night in both areas (Fig. 5c). Fish biomass showed significant differences according to the area (Table 1), with higher biomass on the French shelf, especially during the day period (Fig. 5d). The diel period did not have a significant effect on fish biomass in either area (Table 1). Highly significant differences between 

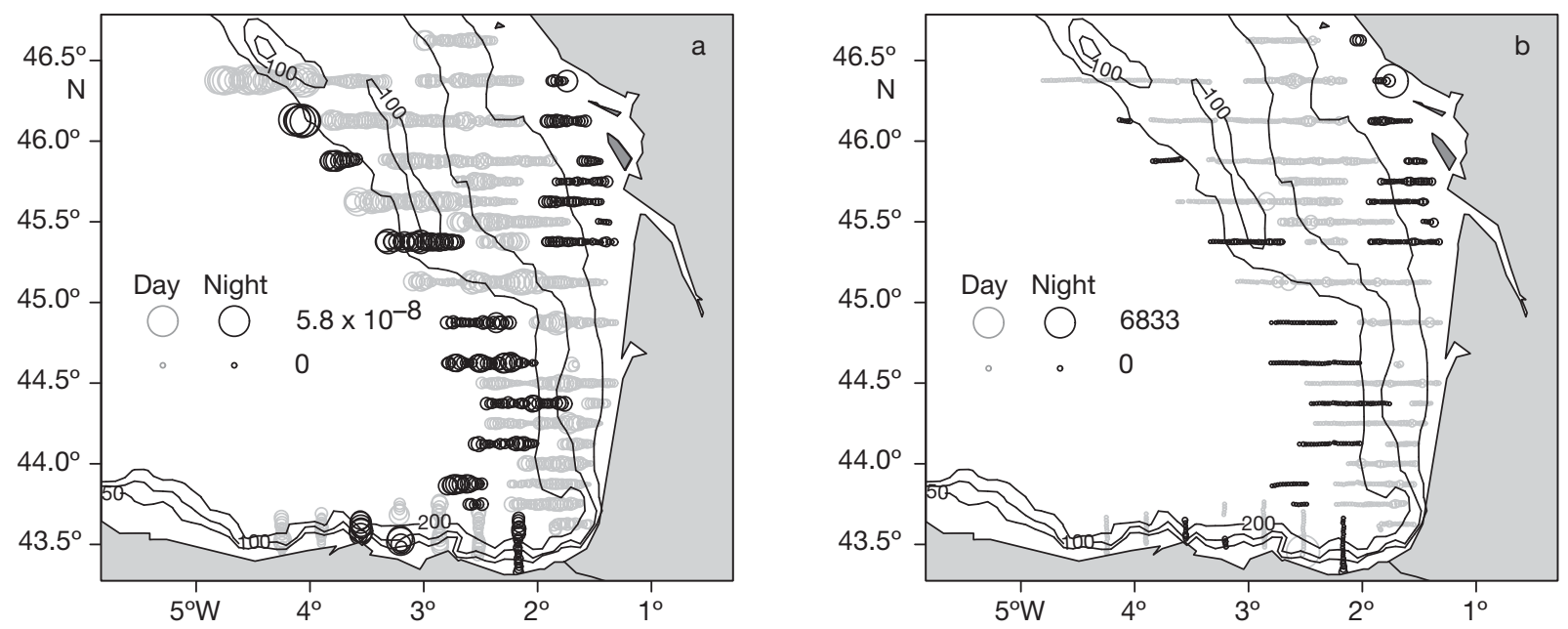

Fig. 4. Day-night distribution of acoustic (a) macrozooplankton $\left(s_{\mathrm{v}} \mathrm{m}^{-1}\right)$ and (b) fish biomass $\left(\mathrm{NASC}_{i} \mathrm{~m}^{2} \mathrm{n} \mathrm{mile}^{-2}\right)$

Table 1. Nested ANOVA of acoustic macrozooplankton and fish biomass according to diel period, shelf areas (Spain or France) and ecological domains (coast, shelf, slope and offshore). Asterisks indicate significant difference: ${ }^{*} \mathrm{p}<0.05_{i}{ }^{* *} \mathrm{p}<0.01 ;{ }^{* * *} \mathrm{p}<$ 0.001 ; NS: not significant

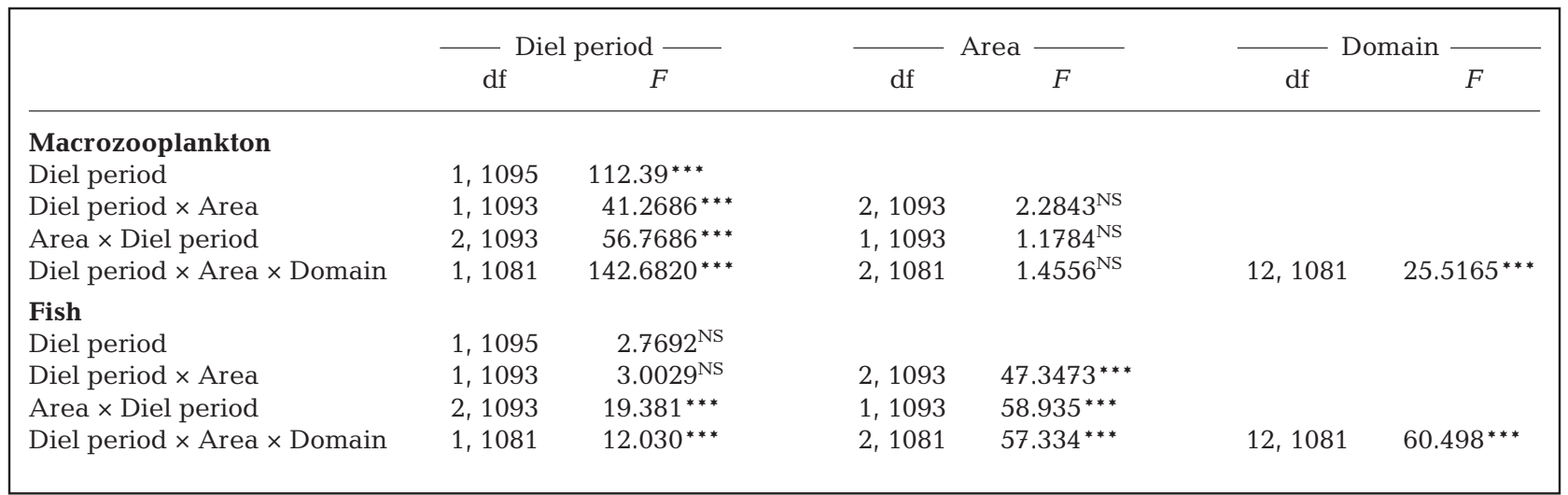

fish biomass and area were observed for both the day and night (Table 1, Fig. 5d).

\section{Ecological domain effect}

Macrozooplankton biomass varied significantly with the ecological domain during the day and night, except in the Spanish area during the day (Tables 1 \& 2). Its biomass increased regardless of the diel period across the continental shelf and towards the offshore region (Fig. 5e,g). This illustrates the importance of the shelf-break as a cut-off point with higher biomasses offshore, in particular during the night. Macrozooplankton biomass increased offshore with the distance to the shelf-break, particularly in the French area (Fig. 6a,c). In the French shelf area, in both the day and night, the macrozooplankton bio- mass showed a relatively smooth distribution pattern across the ecological domains (Fig. 5g) with no significant differences from the shelf onwards (Table 2). In the Spanish shelf area, the macrozooplankton distribution was less regular. There was no pattern at all during the day, and a pronounced coastoffshore gradient (Fig. 5e) with significant differences between inshore and offshore regions at night (Table 2).

Fish biomass also varied significantly with the ecological domains for both diel periods and areas, but with larger differences for areas (Tables $1 \& 2$ ). The effect that the shelf-break had on the distribution of organisms was independent of the diel period (Fig. 6b,d). Fish biomass showed the opposite pattern to the one observed for macrozooplankton, that is, it increased towards the coast during both the night and day (Fig. 5f,h). The fish biomass distribution pat- 

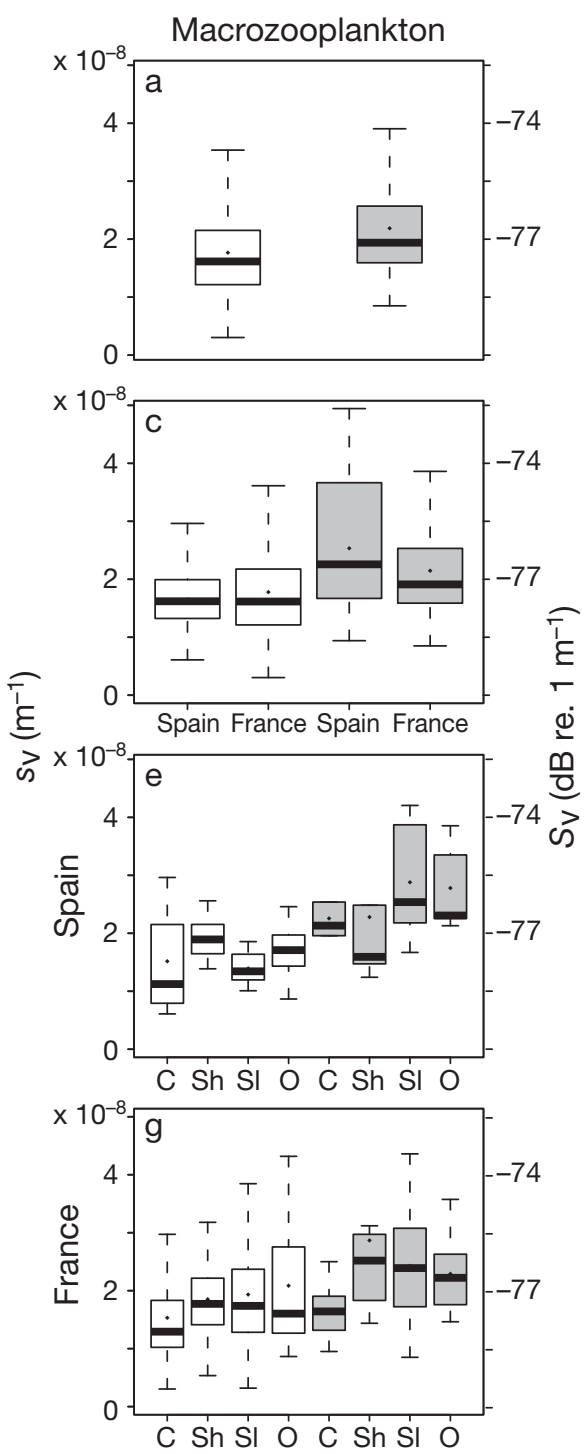

Fig. 5. Day and night box plots of macrozooplankton and fish biomass according to areas and ecological domains. Day (white boxes) and night (grey boxes) distributions are represented according to $(a, b)$ the total area, $(c, d)$ the coastal areas, and $(\mathrm{e}-\mathrm{h})$ the ecological domains. Ecological domains are coast $(\mathrm{C})$, shelf (Sh), slope (Sl) and offshore (O). Dot: mean; bar: median; box: 25th-75th percentiles; whiskers: 5th-95th percentiles. Macrozooplankton acoustic biomass values are in $S_{\mathrm{v}}\left(\mathrm{m}^{-1}\right)$. Corresponding values in $S_{\mathrm{v}}\left(\mathrm{dB}\right.$ re. $\left.1 \mathrm{~m}^{-1}\right)$ are indicated for information purposes only on the right-hand $y$-axis

tern, unlike the macrozooplankton pattern, was constant throughout the diel period and areas. Significant differences between ecological domains were found in almost all cases (Table 2).

\section{Acoustic sizes}

Macrozooplankton biomass and acoustic sizes showed similar across-shore distribution trends with smaller acoustic sizes (higher $\left.\triangle \mathrm{MVBS}_{120-38}\right)$ towards the coast (Fig. 7), coinciding with lower biomass (Fig. 5c).

\section{Geostatistical analysis}

\section{Structural analysis}

The Bay of Biscay has 2 distinct shelves (Spanish and French) that are more or less orthogonal to each other. Therefore, in a preliminary investigation (not shown), we studied the anisotropy and treated data from the 2 shelves separately. For each shelf, 2 directions (north-south and eastwest, corresponding grossly to the along and across contour effects) were considered when the experimental variograms were calculated. No anisotropy in macrozooplankton and fish data was found at the short-distance (i.e. small-scale) lag for either shelf. Likewise, experimental variograms along and across transects (still in the north-south and east-west directions) did not show any anisotropy at the short-distance lag when the 2 shelves were compared. Only a drift for the long-distance lag was found for the macrozooplankton over the French shelf in the east-west direction, which corresponds to the increase in biomass from the coast to offshore. For these reasons we chose to model the Spanish and French data together.

Macrozooplankton showed a significant positive correlation with vertical range (related to east-west drift over the French shelf) and diel period $\left(\mathrm{R}^{2}=\right.$ 0.22 , depth $\mathrm{p}<2 \times 10^{-16}$ and time $\mathrm{p}<$ $2 \times 10^{-16}$; Fig. 8). Thus, both variables were used as external drifts to improve the kriging of the macrozooplankton. The variogram model was inferred based on the residuals and assuming isotropy for every lag. Using the vertical range as external drift meant that an isotropic model could be used for the entire Bay while accounting for the previously observed long-distance lag anisotropy.

The variogram models were fitted to a maximum distance of $150 \mathrm{n}$ mile, including both day and 


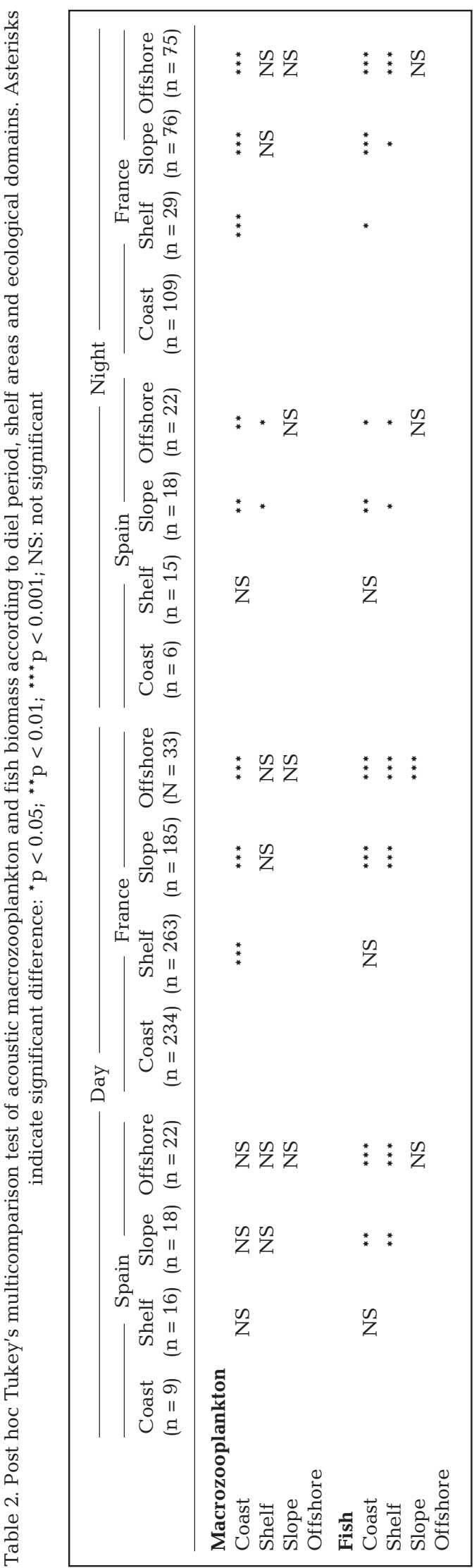

night data. They consisted of a nugget, representing unresolved small-scale variation and observation error, and a structured part. The fish model had a 3-component structure: a nugget effect of 60000 and 2 spherical models with sills of 30000 and 98000 and ranges of 5 and $50 \mathrm{n}$ mile (Fig. 9b). The macrozooplankton model had 3 components: a nugget effect of $0.50 \times 10^{-17}$ and 2 spherical models with sills of $2.80 \times$ $10^{-17}$ and $2.75 \times 10^{-17}$ and ranges of 14 and $80 \mathrm{n}$ mile (Fig. 9a).

Fish and macrozooplankton biomasses showed opposite inshore-offshore trends, as macrozooplankton increased towards oceanic waters and fish decreased. This also occurred for the spatial structures of these 2 populations. Experimental variograms were calculated and models were fitted (nested structures with a nugget, a short- and a long-range spherical component) for inshore and offshore data for each population (Fig. 10).

Offshore, both short- and long-range structures for macrozooplankton showed similar variability. Therefore, both scales of the spatial structure were equally represented in this region. However, inshore, the short-range structure showed larger variability than the long-range structure; thus, the small scale of the spatial structure was more important inshore.

Offshore, fish showed the same pattern as macrozooplankton, with similar variability for both structures. Inshore, the long-range structure showed larger variability aggregate.

\section{Macrozooplankton and fish horizontal distribution}

Interpolated maps of acoustic macrozooplankton and fish biomass confirmed the previous results but provided far more details on the spatial patterns (Fig. 11). In general, fish and macrozooplankton exhibited opposite spatial patterns as zooplankton biomass increased towards oceanic waters, whereas fish biomass decreased.

Zooplankton diel vertical migration was particularly noticeable during the night, in particular in the offshore area. Therefore, 2 separate maps, one for day and one for night data, were used to represent the macrozooplankton distribution.

Some hotspots were detected on both the fish and macrozooplankton maps. The shelf-break was a key feature, both for macrozooplankton and fish. For instance, high values of macrozooplankton biomass occurred at the extreme northeast of the map in the slope/offshore regions $\left(\sim 46-47^{\circ} \mathrm{N}\right)$, and at the Fer à cheval and Capbreton canyon locations (Fig. 11). 

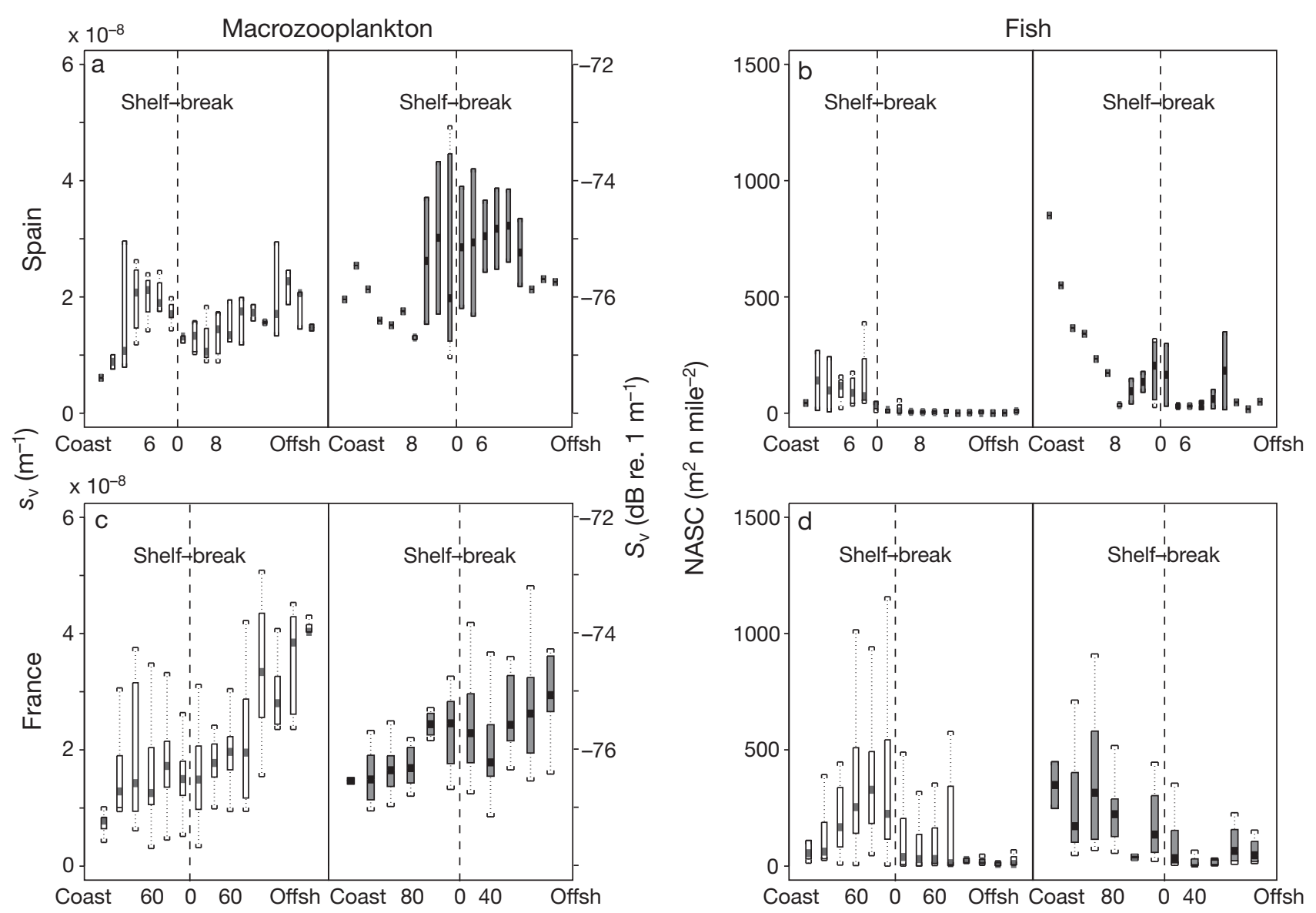

Distance to the shelf-break ( $\mathrm{n}$ mile)

Fig. 6. Day and night box plots (limits as in Fig. 5) of macrozooplankton and fish biomass according to the distance to the shelfbreak. Patterns during the day (white boxes) and night (grey boxes) are shown for (a,b) Spain and (c,d) France. Acoustic macrozooplankton biomass values are in $S_{\mathrm{v}}\left(\mathrm{m}^{-1}\right)$. Corresponding values in $S_{\mathrm{v}}\left(\mathrm{dB}\right.$ re. $\left.1 \mathrm{~m}^{-1}\right)$ are indicated for information purposes only on the right-hand $y$-axis

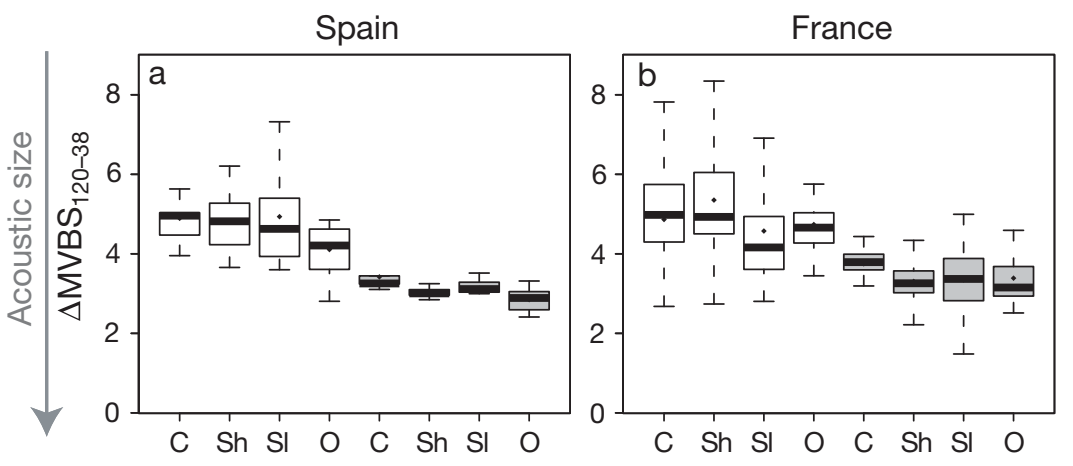

Fig. 7. Day (white) and night (grey) box plots (limits as in Fig. 5) of difference in mean volume backscattering strength $\left(\Delta \mathrm{MVBS}_{120-38}\right)$ (as an indicator of acoustic sizes) for the macrozooplankton in (a) Spain and (b) France in relation to the 4 ecological domains: coast $(\mathrm{C})$, shelf $(\mathrm{Sh})$, slope $(\mathrm{Sl})$ and offshore $(\mathrm{O})$

Another noticeable macrozooplankton aggregation occurred in oceanic waters in the Cantabrian Sea between $2^{\circ} 30^{\prime} \mathrm{W}$ and $3^{\circ} 45^{\prime} \mathrm{W}$.
The 2 main aggregations of fish biomass occurred in the coastal areas, north of the French shelf $\left(46-47^{\circ} \mathrm{N}\right)$ and along the Spanish coast $\left(2-3^{\circ} \mathrm{W}\right)$. A third aggregation was located between 45 and $46^{\circ} \mathrm{N}$, within the 70-200 m bottom-depth zone.

\section{Cross-scale correlation}

A cross-variogram between fish and macrozooplankton was calculated to determine the cross-scale correlation between these 2 populations (Fig. 12). Fish and macrozooplankton were positively correlated at a small scale ( 2 to $30 \mathrm{n}$ mile) and negatively correlated at a larger scale (>30 $\mathrm{n}$ mile). 


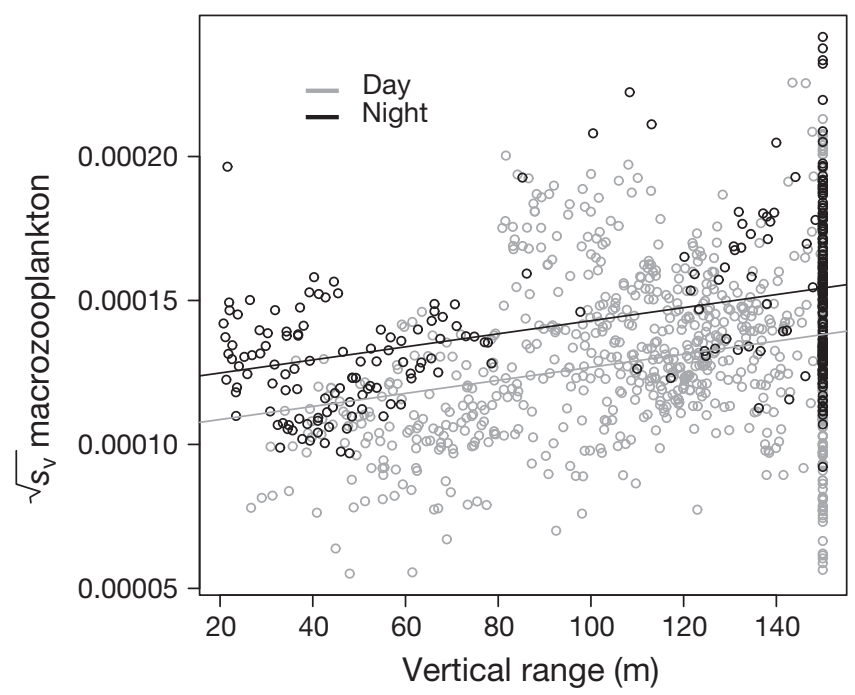

Fig. 8. Drift from diel period and vertical range. Scatter plot between the square root of acoustic macrozooplankton biomass $\left(S_{\mathrm{v}}\right)$ and vertical range, with day values in grey, and night values in black. A linear model has been fitted and represented: $\sqrt{S_{\mathrm{v}}} \approx$ indicator of day + vertical range

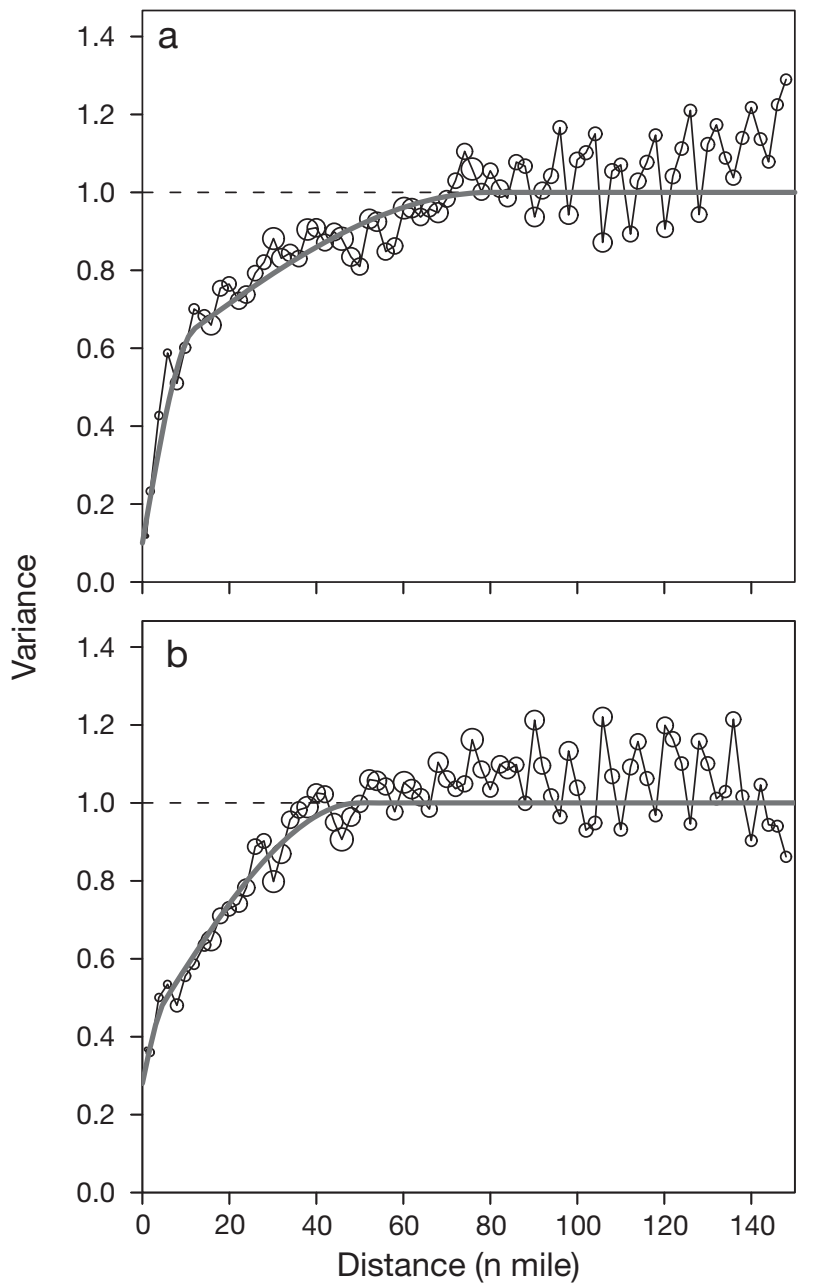

\section{DISCUSSION}

A bi-frequency classification method was applied to acoustic survey data collected during spring 2009 in the Bay of Biscay (Fig. 3). Although it was applied for only $1 \mathrm{yr}$, this method produced 4 major results: (1) the first high-resolution, largescale acoustic description of the macrozooplankton biomass distribution; (2) the comparison of macrozooplankton and fish biomass distribution patterns in relation to the diel cycle; (3) the spatial modelling of these distributions using geostatistics; and (4) evidence of a correlation between pelagic fish and macrozooplankton biomass, positive at a small scale $(<30 \mathrm{n}$ mile) and negative at a larger scale (>30 n mile).

\section{Validation of the bi-frequency classification method}

The main difficulty in validating the acoustic results is the availability of independent biological observations. Net sampling is the most common tool for sampling marine pelagic organisms. Unfortunately, the confidence levels in net biomass estimations are either high or low depending on the type of nets and the target species (Fleminger \& Clutter 1965, McGowan \& Fraundorf 1966, Gorbatenko \& Dolganova 2006). The problem is particularly crucial for macrozooplankton, which are capable of avoiding nets (Debby et al. 2004). This and the lack of comprehensive information on macrozooplankton in the Bay of Biscay make it difficult to determine which groups compose the observed macrozooplankton. Therefore, we will discuss our results according to the well-known broad patterns of macrozooplankton distribution (e.g. Blackburn 1979, Barange \& Pillar 1992, Swartzman et al. 2005, Ballón et al. 2011).

It was less difficult, however, to differentiate the pelagic swimbladder-bearing fish because the main research institutes in this area routinely study the fish biomass distribution with acoustic methods (from a single frequency) and use ground-truth catch data for validation (Massé 1996, Massé et al. 1996, Boyra

Fig. 9. Experimental variograms and corresponding models used for the kriging for (a) macrozooplankton (inferred from the residuals) and (b) fish (log-back transformed). Symbol area is proportional to the number of pairs involved in the calculation for each distance lag. Variograms are normalized to the sample variance for comparison purposes only 

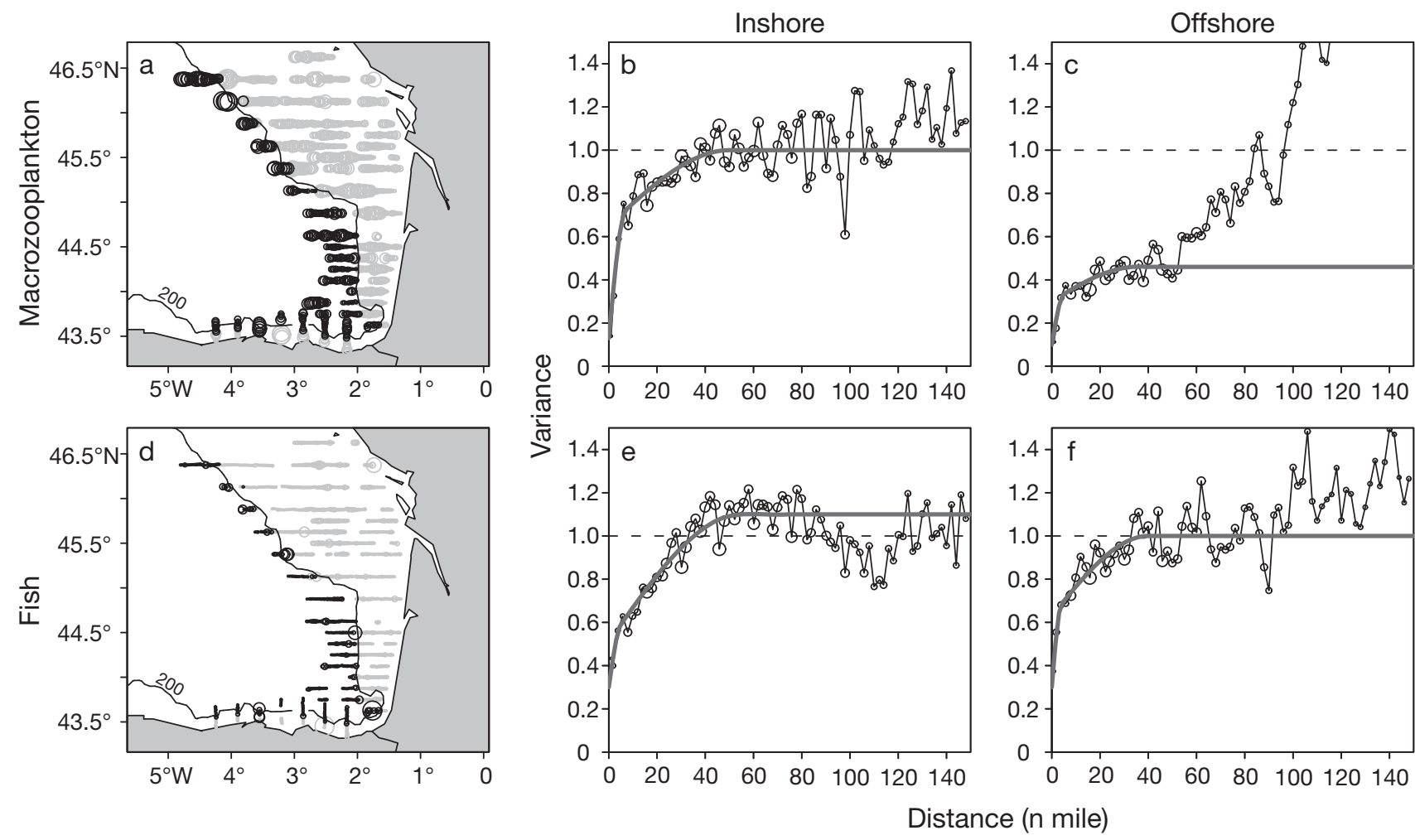

Fig. 10. Inshore-offshore structural analysis of macrozooplankton and fish. (a,d) Proportional representation of biomass; inshore values $(0-150 \mathrm{~m})$ are in grey whereas offshore values (>150 m bottom depth) are in black. Normalized experimental variograms of the $(\mathrm{b}, \mathrm{e})$ inshore and $(\mathrm{c}, \mathrm{f})$ offshore biomass and their corresponding models. Symbol area is proportional to the number of pairs involved in the calculation for each distance lag. Fish variograms are log back-transformed

\& Uriarte 2006, G. Boyra et al. unpubl.). Thus, although the distribution and ecology of pelagic fish have been studied in the Bay of Biscay for over 2 decades, little is known about macrozooplankton.

\section{Diel patterns of distribution}

\section{Macrozooplankton}

As expected, the macrozooplankton biomass in the upper layer (from the surface to $150 \mathrm{~m}$ ) was significantly higher during the night than during the day. The nocturnal macrozooplankton biomass is composed of migratory and non-migratory macrozooplankton (Fernández de Puelles et al. 1996, Poulet et al. 1996, Maycas et al. 1999). Migratory organisms were not included in the biomass estimated during the day, as they were mainly distributed at approximately $400 \mathrm{~m}$, which is deeper than our acoustic range of $150 \mathrm{~m}$.

Based on the difference between the day and night biomass, we estimated the migrating macrozooplankton biomass to be $19 \%$ offshore and $10 \%$ inshore. These inshore-offshore differences were expected (e.g. Ballón et al. 2011) and could be due to the fact the acoustic vertical range covers most of the water column inshore and most of the migrating communities are distributed offshore.

\section{Horizontal distribution}

When mapping, the spatial distributions of macrozooplankton and pelagic fish may be questionable. Indeed, macrozooplankton and pelagic fish are known to form aggregations/schools during the day that disperse during the night, and also to perform 

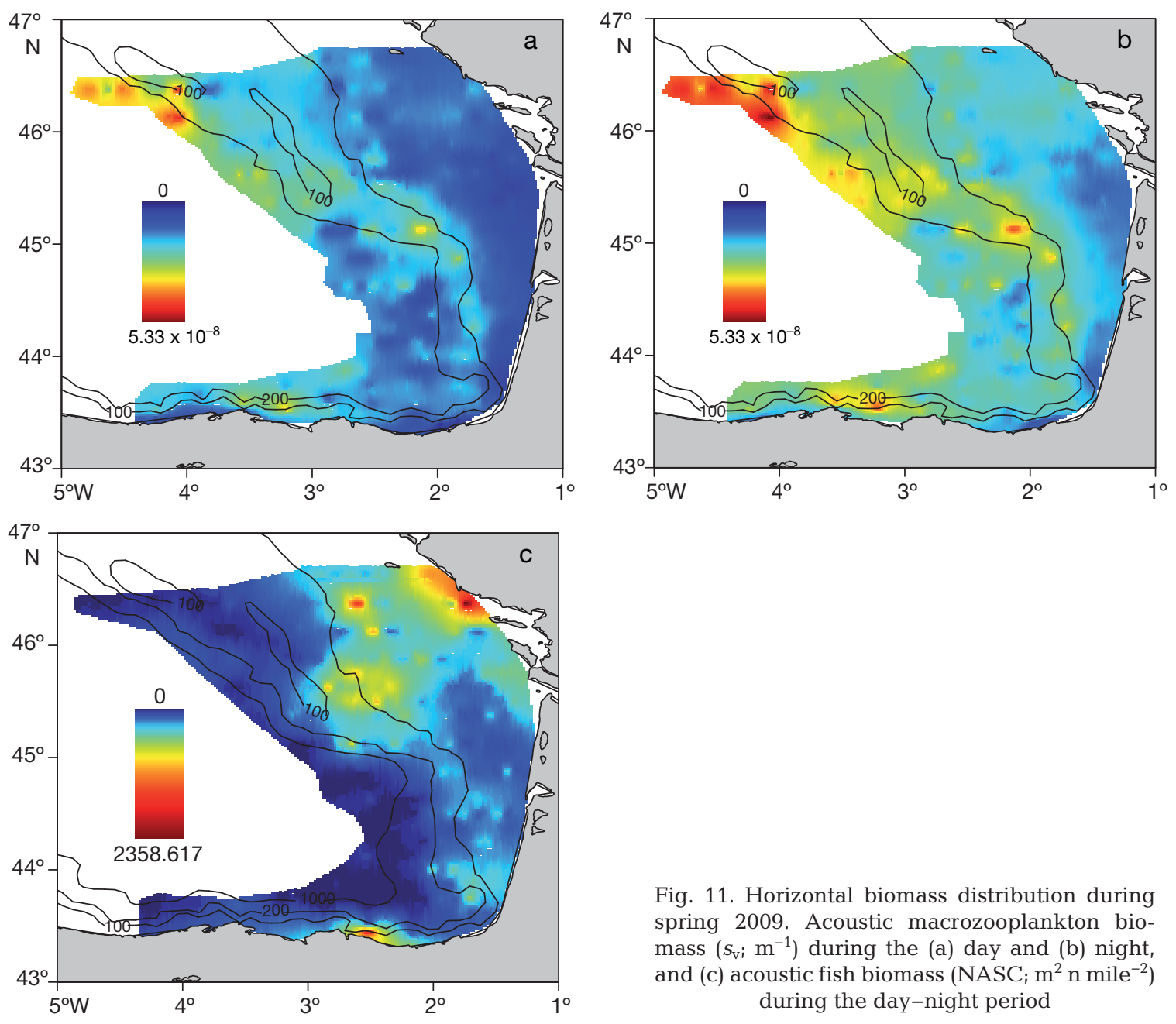

Fig. 11. Horizontal biomass distribution during spring 2009. Acoustic macrozooplankton biomass $\left(s_{\mathrm{v}} ; \mathrm{m}^{-1}\right)$ during the (a) day and (b) night, and (c) acoustic fish biomass (NASC; $\mathrm{m}^{2} \mathrm{n}$ mile ${ }^{-2}$ ) during the day-night period

diel vertical migration. However, the scale at which these phenomena occur is mostly below our sampling lag (elementary sampling distance unit $<1 \mathrm{n}$ mile). Thus, the modelled spatial structures (using day and night data) are acceptable and correspond to at least that of the clusters of macrozooplankton or fish aggregations.

\section{Macrozooplankton}

The highest biomasses of macrozooplankton were found in areas adjacent to the shelf-break: Capbreton and Cap Ferret canyons, the Fer à cheval region, the Spanish slope and the northwestern French shelf. The shelf-break thus constitutes an important feature for retaining and accumulating macrozooplankton offshore and over the slope in the Bay of Biscay. Similar observations have been made in other systems (e.g. Bakun 1996, Genin 2004, Zhu et al. 2009, Ballón et al. 2011).

The acoustic sizes of macrozooplankton were also higher offshore (smaller $\triangle$ MVBS $_{120-38}$ ). This suggests a shift in species composition towards organisms such as euphausiids or large copepods. The significant shelf-break effect on macrozooplankton biomass and acoustic size is similar to the effect that has been observed on the composition of mesozooplankton communities, which shift from small to large mesozooplankton (Sourisseau \& Carlotti 2006, Albaina \& Irigoien 2007, Irigoien et al. 2009).

Fish

Fish were distributed differently than macrozooplankton. High biomasses were found in the coastal regions, mostly over the French shelf area. The densest fish aggregations were observed inshore on the northern platform (46 and $47^{\circ} \mathrm{N}$ ), in the inner shelf area in front of the Gironde River plume $\left(45^{\circ} 10^{\prime} \mathrm{N}\right)$, in 


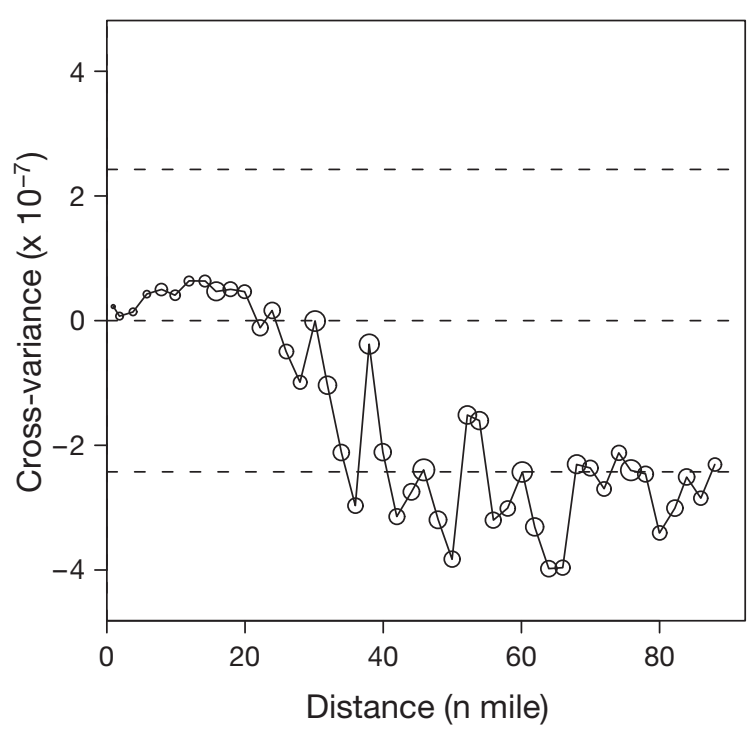

Fig. 12. Isotropic cross-variogram illustrating the cross-scale correlation between fish and macrozooplankton biomass. Dashed lines represent the positive, null and negative sample cross-variances, from top to bottom

the outer shelf area between 70 and $150 \mathrm{~m}$ depth, and along the Spanish coast $\left(2-3^{\circ} \mathrm{W}\right)$. Other, less dense aggregations were found offshore on the southern platform related to the Adour River plume and shelf edge fronts (which defined the area between the Capbreton and Cap Ferret canyons, and Fer à cheval region). Similar patterns were observed during both annual spring surveys (PELGAS and BIOMAN) performed to estimate the biomass of small pelagic species in the Bay of Biscay (ICES 2009).

This distribution agrees with the habitat preferences of the main pelagic species (anchovy, sardine and horse mackerel) during spring. Small clupeiformes, especially young anchovies and sardines, prefer coastal habitats and river mouths (Motos et al. 1996, Planque et al. 2007), which has been related to the favourable conditions (increased biological production) produced by the high river runoff (Gironde, Loire and Adour; Fig. 1), by nutrient inputs from deeper waters (coastal upwellings) and by low vertical mixing (haline and thermal stratification, Lazure \& Jegou 1998, Puillat et al. 2004). This makes the French inner shelf a more suitable area for these fish during the spawning season than the Spanish shelf.

However, horse mackerel and older anchovies ( $\geq 2 \mathrm{yr}$ old) show more affinity for outer-shelf regions, and occasionally approach the shelf-break (Abaunza et al. 2003), which, according to Motos et al. (1996), occurs in the Fer à cheval region, along the French shelf near Capbreton canyon and in the Cantabrian Sea, west of $2^{\circ} \mathrm{W}$.

\section{Fish-macrozooplankton interactions}

Aggregation scale

During recent decades, numerous studies have focused on characterizing the spatial patterns of the pelagic fish in the Bay of Biscay (e.g. Petitgas 1998, 2000, Petitgas et al. 2003, Woillez 2007). Nonetheless, little is known about the spatial patterns of zooplankton (López-Jamar et al. 1991), and nothing about those of macrozooplankton. The present study revealed that the macrozooplankton biomass was structured spatially at 2 different ranges: a short one at $14 \mathrm{n}$ mile and a longer one at $80 \mathrm{n}$ mile. The fish spatial structure also showed 2 different ranges: a small one at $5 \mathrm{n}$ mile and a larger one at $50 \mathrm{n}$ mile. Previous studies have also observed a 2-scale spatial structure: 4 and $19 \mathrm{n}$ mile for pelagic fish in Petitgas (2000), and 10 and $75 \mathrm{n}$ mile for anchovy in Woillez (2007). These differences illustrate the annual variability of the aggregation patterns related to changes in the specific composition of the main communities and to the oceanographic forcing (Bertrand et al. 2008).

It is interesting to note that fish and macrozooplankton aggregation scales were similar offshore $(5-4 \mathrm{n}$ mile for the small-medium scale and 40-35 $\mathrm{n}$ mile for the large scale). Bertrand et al. (2008) described similar associations between fish and zooplankton aggregation scales in the Humboldt Current system, and suggested that mesoscale (10s of $\mathrm{km}$ ) physical forces (e.g. upwelling/downwelling, tidal fronts and river discharges) shape the distribution of zooplankton patches given that there is motivation for feeding, which indirectly influences the fish patch size. However, we would also expect to obtain the same aggregation scales between macrozooplankton and fish inshore, where most of the fish biomass occurs, but this was not the case. Young anchovies and sardines mainly forage on small-sized prey, e.g. micro- and meso-zooplankton (ca. small-size copepods) that dominate inshore zooplankton (Irigoien et al. 2009), which are not well represented in our data (zooplankton $>\sim 2 \mathrm{~mm}$ ). However, older anchovies ( $\geq 2 \mathrm{yr}$ old) and horse mackerel, which are usually located at the shelf-break (Motos et al. 1996), forage on larger prey (e.g. Blaxter \& Hunter 1982, Van der Lingen et al. 2009) belonging to mesozooplankton (ca. mediumsize copepods) and macrozooplankton (ca. large copepods and euphausiids). This may explain why we found the same aggregation scales between fish and macrozooplankton in the offshore region where the fish prey field is accurately observed, and not inshore where the fish prey field is not or partially observed. 


\section{Scale-dependent predator-prey relationships}

The cross-variograms showed that macrozooplankton and fish biomass were positively correlated at small scales (<30 n mile) and negatively correlated at larger scales (>30 $\mathrm{n}$ mile). These results appear to contradict the classic theory on predator-prey spatial interactions (Rose \& Leggett 1990) in which negative correlations occur at small scales and positive ones at larger scales. In our case, the negative relationship observed on a large scale illustrates that fish and macrozooplankton are distributed in different regions (inshore and offshore). The positive relationship between macrozooplankton and fish biomass at the small scale indicates that, locally, fish concentrate at macrozooplankton patches. Genin (2004) observed similar positive local relationships along topographically generated fronts, for instance seamounts, canyons and shelf-breaks. Zooplankton aggregations have a certain degree of permanence above these features, and attract planktivorous fish species (Sameoto 1976, Simmard et al. 1986, Bertrand et al. 2008). However, our data do not address the real small scale sensu Rose \& Leggett (1990). The smallest scale considered was $1 \mathrm{n}$ mile (cross-variogram lag), which is probably appropriate for determining that fish are attracted to macrozooplankton hotspots; however, it does not allow us to study the very small scale where fish and macrozooplankton interact, and where depletion (negative relation) can be observed.

\section{CONCLUSIONS}

Simultaneous high-resolution data on both macrozooplankton and pelagic fish were used to provide a better understanding of the spatial processes and interactions in the Bay of Biscay pelagic ecosystem. Macrozooplankton and fish showed opposite largescale distribution patterns as macrozooplankton biomass was higher offshore than inshore and the reverse was true for fish. The shelf-break is a key feature for macrozooplankton because it is both a hotspot and the limit between low and high abundance. The aggregation scales followed a similar trend because larger aggregations predominated offshore for macrozooplankton and inshore for fish. These opposed large-scale distribution patterns lead to a negative correlation between the fish and macrozooplankton distributions at scales $>30 \mathrm{n}$ mile. However, the correlation was positive at scales $<30 \mathrm{n}$ mile, which indicates that fish concentrate where macrozooplankton is more abundant. Further analyses that include environmental factors need to be performed in order to better understand the mechanism responsible for the observed patterns. The availability of ground-truth data of suspected macrozooplankton echosigns should allow us to transform an acoustic biomass into an absolute biomass, which will be another step towards understanding trophic interactions better and, more generally, extending ecosystem management by including non-exploited organisms.

Acknowledgements. This work was supported by the ECOANCHOA project funded by the Department of Agriculture and Fisheries of the Basque Government and the Ministry of Agriculture, Fishery and Food (MAPA), of the Spanish Government and a grant to A.L.-O. (Technological Centre Foundation). We are grateful to the crew of the RV 'Investigador' and the onboard scientists and analysts for their support during this work. We also thank U. Martinez and G. Boyra (Tecnologico Pesquero y Alimentario [AZTITecnalia]) for their help. This work has also benefited from the cooperation agreement between the Institut de Recherche pour le Développement and the Instituto del Mar del Perú and from the International Joint Laboratory Dynamics of the Humboldt Current System. This paper is contribution no. 555 from AZTI-Tecnalia.

\section{LITERATURE CITED}

Abaunza P, Gordo L, Karlou-Riga C, Murta A and others (2003) Growth and reproduction of horse mackerel, Trachurus trachurus (Carangidae). Rev Fish Biol Fish 13: $27-61$

> Albaina A, Irigoien X (2007) Fine scale zooplankton distribution in the Bay of Biscay in spring 2004. J Plankton Res 29:851-870

Bakun A (1996) Patterns in the ocean: ocean processes and marine population dynamics. University of California Sea Grant, San Diego, CA, in cooperation with Centro de Investigaciones Biológicas de Noroeste, La Paz, Baja California Sur

Ballón M (2010) Acoustic study of macrozooplankton off Peru: biomass estimation, spatial patterns, impact of physical forcing and effect on forage fish distribution. $\mathrm{PhD}$ thesis, University Montpellier II

Ballón M, Bertrand A, Lebourges-Dhaussy A, Gutiérrez M, Ayón P, Grados D, Gerlotto F (2011) Is there enough zooplankton to feed forage fish population off Peru? An acoustic (positive) answer. Prog Oceanogr (in press) doi: 10.1016/j.pocean.2011.03.001

Barange M, Pillar S (1992) Cross-shelf circulation, zonation and maintenance mechanisms of Nyctiphanes capensis and Euphausia hanseni (Euphausiacea) in the northern Benguela upwelling system. Cont Shelf Res 12: 1027-1042

Beaudouin J (1971) Données écologiques sur quelques groupes planktoniques indicateurs dans le Golfe de Gascogne. Rev Trav Inst Pech Marit 35:375-414

Beaudouin J (1975) Copepodes du plateau continental du Golfe de Gascogne en 1971 et 1972. Rev Trav Inst Pech Marit 39:121-169 
Beaudouin J (1979) Euphausiaces, mysidaces, larves de decapodes du Golfe de Gascogne (plateau continental) en 1971 et 1972. Rev Trav Inst Pech Marit 43:367-389

Bertrand A, Josse E, Bach P, Dagorn L (2003) Acoustics for ecosystem research: lessons and perspectives from a scientific programme focusing on tuna-environment relationships. Aquat Living Resour 16:197-203

- Bertrand A, Gerlotto F, Bertrand S, Gutiérrez M and others (2008) Schooling behaviour and environmental forcing in relation to anchoveta distribution: an analysis across multiple spatial scales. Prog Oceanogr 79:264-277

Blackburn M (1979) Zooplankton in an upwelling area off northwest Africa: composition, distribution and ecology. Deep-Sea Res I 24:41-56

Blaxter JHS, Hunter JR (1982) The biology of the clupeoid fishes. Adv Mar Biol 20:1-223

Boyra G, Uriarte A (2006) Acoustic surveying of anchovy juveniles in the Bay of Biscay: JUVENA 2005 survey results and 2003-2005 biomass estimates. Working Document to ICES Working Group on the Assessment of Mackerel, Horse Mackerel, Sardine and Anchovy, Galway

Brinton E (1967) Vertical migration and avoidance capability of euphausiids in the California current. Bull Scripps Inst Oceanogr Univ Calif 12:451-483

Carlotti F, Poggiale JC (2010) Towards methodological approaches to implement the zooplankton component in 'end to end' food-web models. Prog Oceanogr 84:20-38

Chilès JP, Delfiner RP (1999) Geostatistics: modeling spatial uncertainty. John Wiley \& Sons, New York, NY

Cressie N (1993) Statistics for spatial data. John Wiley \& Sons, New York, NY

Debby L, Jackson GA, Angel MV, Lampitt RS, Burd AB (2004) Effect of net avoidance on estimates of diel vertical migration. Limnol Oceanogr 46:2297-2303

Fernandes PG, Korneliussen RJ, Lebourges-Dhaussy A, Masse J and others (2006) The SIMFAMI Project: species identification methods from acoustic multifrequency information. Final Report to the EC, Q5RS-2001-02054

Fernández de Puelles ML, Valdés L, Varela M, AlvarezOsorio MT, Halliday N (1996) Diel variations in the vertical distribution of copepods off the north coast of Spain. ICES J Mar Sci 53:97-106

$>$ Fleminger A, Clutter RI (1965) Avoidance of towed nets by zooplankton. Limnol Oceanogr 10:96-104

Foote KG, Knudsen HP, Vestnes G (1987) Calibration of acoustic instruments for fish density estimation: a practical guide. ICES Coop Res Rep 144:1-70

> Genin A (2004) Bio-physical coupling in the formation of zooplankton and fish aggregations over abrupt topographies. J Mar Syst 50:3-20

Gil J, Valdés L, Moral M, Sánchez R, Garcia-Soto C (2002) Mesoscale variability in a high-resolution grid in the Cantabrian Sea (southern Bay of Biscay), May 1995. Deep-Sea Res I 49:1591-1607

Goovaerts P (1997) Geostatistics for natural resources evaluation. Oxford University Press, Oxford

Gorbatenko KM, Dolganova NT (2006) Comparing the catch efficiency with different types of plankton nets in the high production zones of the Pacific Ocean. Oceanology 47:205-212

Guiblin P, Rivoirard J, Simmonds EJ (1995) Analyse structurale de données à distribution dissymétrique: exemple du hareng écossais. Cah Geostat 5:137-159

Haury LR, McGowan JA, Wiebe PH (1978) Patterns and processes in the time-space scales of plankton distributions.
In: Steele JH (ed) Spatial pattern in plankton communities. Plenum Press, New York, NY, p 277-327

> Huskin I, Elices MJ, Anadón R (2003) Salp distribution and grazing in a saline intrusion off NW Spain. J Mar Syst 42: $1-11$

ICES (2009) Report of the Working Group on Acoustic and Egg Surveys for Sardine and Anchovy in ICES Areas VIII and IX (WGACEGG), 16-20 November 2009, Lisbon. ICES CM 2009/LRC:20

> Irigoien X, Fernandes JA, Grosjean P, Denis K, Albaina A, Santos M (2009) Spring zooplankton distribution in the Bay of Biscay from 1998 to 2006 in relation with anchovy recruitment. J Plankton Res 31:1-17

Journel AG, Huijbregts CJ (1978) Mining geostatistics. Academic Press, London

Kloser RJ, Ryan T, Sakov P, Willliams A, Koslow JA (2002) Species identification in deep water using multiple acoustic frequencies. Can J Fish Aquat Sci 59:1065-1077

Korneliussen R (2000) Measurement and removal of echo integration noise. ICES J Mar Sci 57:1204-1217

Korneliussen RJ, Ona E (2003) Synthetic echograms generated from the relative frequency response. ICES J Mar Sci 60:636-640

Korneliussen RJ, Diner N, Ona E, Berger L, Fernandes PG (2008) Proposals for the collection of multifrequency acoustic data. ICES J Mar Sci 65:982-994

$>$ Koslow JA (2009) The role of acoustics in ecosystem-based fishery management. ICES J Mar Sci 66:966-973

- Lawson GL, Wiebe PH, Ashjian CJ, Stanton TK (2008) Euphausiid distribution along the Western Antarctic Peninsula - Part B: distribution of euphausiid aggregations and biomass, and associations with environmental features. Deep-Sea Res II 55:432-454

> Lazure P, Jegou A (1998) 3D modelling of seasonal evolution of Loire and Gironde plumes on Biscay Bay continental shelf. Oceanol Acta 21:165-177

Lezama-Ochoa A, Boyra G, Goñi N, Arrizabalaga H, Bertrand A (2010) Investigating relationships between albacore tuna (Thunnus alalunga) CPUE and prey distribution in the Bay of Biscay. Prog Oceanogr 86:105-114

López-Jamar E, Coombs SH, Alemany F, Alonso J and others (1991) A SARP pilot study for sardine (Sardina pilchardus) off north and northwest Spain in April/May 1991. ICES CM 1991/L:9

> Mackas DL, Beaugrand G (2010) Comparisons of zooplankton time series. J Mar Syst 79:286-304

- MacLennan DN, Fernandes PG, Dalen J (2002) A consistent approach to definitions and symbols in fisheries acoustics. ICES J Mar Sci 59:365-369

Massé J (1996) Acoustic observations in the Bay of Biscay: schooling, vertical distribution, species assemblages and behaviour. Sci Mar 60:227-234

> Massé J, Koutsikopoulos C, Patty W (1996) The structure and spatial distribution of pelagic fish schools in multispecies clusters: an acoustic study. ICES J Mar Sci 53:155-160

- Maycas ER, Bourdillon AH, Macquart-Moulin C, Passelaigue F, Patriti G (1999) Diel variations of the bathymetric distribution of zooplankton groups and biomass in Cap-Ferret Canyon, France. Deep-Sea Res II 46: 2081-2099

> McGowan JA, Fraundorf VJ (1966) The relationship between size of net used and estimates of zooplankton diversity. Limnol Oceanogr 11:456-469

Mitra A, Davis C (2010) Defining the 'to' in end-to-end models. Prog Oceanogr 84:39-42 
Mitson RB, Simard Y, Goss C (1996) Use of a two-frequency algorithm to determine size and abundance of plankton in three widely spaced locations. ICES J Mar Sci 53: 209-215

Motos L, Uriarte A, Valencia V (1996) Egg production of the Bay of Biscay anchovy population (Engraulis encrasicolus L.) in relation to environmental features. Sci Mar 60: $117-140$

Murase H, Ichihara M, Yasuma H, Watanabe $\mathrm{H}$ and others (2009) Acoustic characterization of biological backscatterings in the Kuroshio-Oyashio inter-frontal zone and subarctic waters of the western North Pacific in spring. Fish Oceanogr 18:386-401

Ohman MD, Smith PE (1995) A comparison of zooplankton sampling methods in the CalCOFI time series. CCOFI Rep 36:153-158

Omori M, Hamner WM (1982) Patchy distribution of zooplankton: behavior, population assessment and sampling problems. Mar Biol 72:193-200

Petitgas P (1993) Geostatistics for fish stock assessments: a review and an acoustic application. ICES J Mar Sci 50: 285-298

Petitgas P (1998) Biomass-dependent dynamics of fish spatial distributions characterized by geostatistical aggregation curves. ICES J Mar Sci 55:443-453

Petitgas P (2000) On the clustering of fish schools at two scales and their relation with meso-scale physical structures. ICES CM 2000/K:25

Petitgas P, Massé J, Beillois P, Lebarbier E, Le Cann A (2003) Sampling variance of species identification in fisheries acoustic surveys based on automated procedures associating acoustic images and trawl hauls. ICES J Mar Sci 60: 437-445

Planque B, Bellier E, Lazure P (2007) Modelling potential spawning habitat of sardine (Sardina pilchardus) and anchovy (Engraulis encrasicolus) in the Bay of Biscay. Fish Oceanogr 16:16-30

Poulet SA, Laabir M, Chaudron Y (1996) Characteristic features of zooplankton in the Bay of Biscay. Sci Mar 60(Suppl 2):79-95

> Puillat I, Lazure P, Jégou AM, Lampert L, Miller PI (2004) Hydrographical variability on the French continental shelf in the Bay of Biscay, during the 1990s. Cont Shelf Res 24:1143-1163

Quevedo M, Anadón R (2000) Spring microzooplankton composition biomass and potential grazing in the central cantabrian coast (southern Bay of Biscay). Oceanol Acta 23:297-309

Rivoirard J, Wieland K (2001) Correcting for the effect of daylight in abundance estimation of juvenile haddock (Melanogrammus aeglefinus) in the North Sea: an application of kriging with external drift. ICES J Mar Sci 58: 1272-1285

Rivoirard J, Simmonds J, Foote KG, Fernandes P, Bez N (2000) Geostatistics for estimating fish abundance. Blackwell Science, Oxford

Robinson C, Steinberg DK, Anderson TR, Arístegui J and others (2010) Mesopelagic zone ecology and biogeochemistry: a synthesis. Deep-Sea Res I 57:1504-1518

Rose GA, Leggett WC (1990) The importance of scale to predator-prey spatial correlations: an example of Atlantic Fishes. Ecology 71:33-43

Editorial responsibility: Nicholas Tolimieri,

Seattle, Washington, USA
Sameoto DD (1976) Distribution of sound scattering layers caused by euphausiids and their relationship to chlorophyll a concentrations in the Gulf of St. Lawrence estuary. J Fish Res Board Can 33:681-687

Siegel V (2000) Krill (Euphasia superba) demography and variability in abundance and distribution. Can J Fish Aquat Sci 53:151-167

- Simard Y, Legendre P, Lavoie G, Marcotte D (1992) Mapping, estimating and optimising sampling of spatially autocorrelated data: case study of the northern shrimp. Can J Fish Aquat Sci 49:32-45

Simmard Y, Lacroix G, Legendre L (1986) Diel vertical migrations and nocturnal feeding of a dense coastal krill scattering layer (Nysanoessa raschi and Meganyctiphanes norvegica) in stratified surface waters. Mar Biol 91:93-105

Sourisseau M, Carlotti F (2006) Spatial distribution of zooplankton size spectra on the French continental shelf of the Bay of Biscay during spring 2000 and 2001. J Geophys Res Oceans 111:C05S09, doi:10.1029/2005JC 003063

> Stanton TK, Chu D, Wiebe PH (1996) Acoustic scattering characteristics of several zooplankton groups. ICES J Mar Sci 53:289-295

Stanton TK, Chu D, Wiebe PH (1998) Sound scattering by several zooplankton groups. I. Experimental determination of dominant scattering mechanisms. J Acoust Soc Am 103:225-235

Swartzman G, Hickey B, Kosro M, Wilson C (2005) Poleward and equatorward currents in the Pacific Eastern Boundary Current in summer 1995 and 1998 and their relationship to the distribution of euphausiids. Deep-Sea Res II 52:73-88

Urick RJ (1986) Ambient noise in the sea. Peninsula Publishing, Los Altos, CA

Van der Lingen CD, Bertrand A, Bode A, Brodeur R and others (2009) Trophic dynamics. In: Checkley DM Jr, Roy C, Alheit J, Oozeki Y (eds) Climate change and small pelagic fish. Cambridge University Press, Cambridge, p 112-157

Verheye HM, Richardson AJ (1998) Long-term increase in crustacean zooplankton abundance in the southern Benguela upwelling region (1951-1996): Bottom-up or top-down control? ICES J Mar Sci 55:803-807

Watkins JL, Brierley AS (2002) Verification of the acoustic techniques used to identify Antarctic krill. ICES J Mar Sci 59:1326-1336

- Wiebe PH, Morton AW, Bradley AM, Backus RH and others (1985) New development in the MOCNESS, an apparatus for sampling zooplankton and micronekton. Mar Biol 87:313-323

Wieland K, Rivoirard J (2001) A geostatistical analysis of IBTS data for age 2 North Sea haddock (Melanogrammus aeglefinus) considering daylight effects. Sarsia 86: 503-516

Woillez M (2007) Contributions géostatistiques à la biologie halieutique. Thèse de Docteur en Géostatistique, Ecole Nationale Supérieure des Mines de Paris

Zhu Y, Tande K, Zhou M (2009) Mesoscale physical processes and zooplankton transport-retention in the northern Norwegian shelf region. Deep-Sea Res II 56: 1922-1933

Submitted: March 18, 2011; Accepted: July 22, 2011

Proofs received from author(s): October 2, 2011 